\title{
PEMETAAN JALUR KERETA API RAWAN KECELAKAAN LINTAS \\ JATI NEGARA - JAKARTA KOTA \\ (SURVAI DI JAKARTA, KOTA)
}

\author{
Nico Djajasinga \\ Sekolah Tinggi Transportasi Darat \\ Jln. Raya Setu KM 3,5Cibuntu, Cibitung, \\ Bekasi \\ Tlp : (021) 8254640 \\ Fax : (021) 8254640

\section{Tarli} \\ Sekolah Tinggi Transportasi Darat \\ Jln. Raya Setu KM 3,5Cibuntu, Cibitung, \\ Bekasi \\ Tlp : (021) 8254640 \\ Fax : (021) 8254640
}

\author{
Djoko Septanto \\ Sekolah Tinggi Transportasi Darat \\ Jln. Raya Setu KM 3,5Cibuntu, Cibitung, \\ Bekasi \\ Tlp : (021) 8254640 \\ Fax : (021) 8254640 \\ Ubaini Rasyid \\ Sekolah Tinggi Transportasi Darat \\ Jln. Raya Setu KM 3,5Cibuntu, Cibitung, \\ Bekasi \\ Tlp : (021) 8254640 \\ Fax : (021) 8254640
}

\begin{abstract}
Jatinegara cross the railway line - Jakarta Kota has a length of $11.5 \mathrm{~km}$ rail station with the past 9 that the condition of the track above the highway (pass over railway). While the track is above ground level across 5 stations with eight crossings, and 2 bridge. Strip is also prone to flooding , especially in Kampung Bandan Station and Jakarta Kota

By analysis of the potential for accidents in railway lines and bridges, the analysis of the potential for accidents at level crossings, analysis of potential accidents around densely populated, and the analysis of potential accidents at the station emplacement obtained types of accidents often occur, the cause of the accident, and how the accident chronology.

From the analysis in this study may provide input to PT. Commuter train line in Jakarta to make improvements to the strip area that is prone to accidents such as sterilization activity around the railway track and the manufacture of non-level access ( underpasses or elevated lines)
\end{abstract}

Key words : Key words : Staff participation, coordination directives, and vertical communication

\section{ABSTRAKSI}

Jalur kereta api lintas Jatinegara - Jakarta Kota memiliki panjang 11,5 km sepur dengan melewati 9 stasiun yang kondisi jalurnya berada di atas jalan raya (over pass railway). Sedangkan jalur yang berada di atas permukaan tanah melintasi 5 stasiun dengan 8 perlintasan sebidang, dan 2 jembatan.Jalur tersebut juga rawan terhadap banjir khususnya di Stasiun Kampung Bandan dan Jakarta Kota.

Dengan analisis potensi kecelakaan di jalur dan jembatan KA, analisis potensi kecelakaan di perlintasan sebidang, analisis potensi kecelakaan di sekitar pemukiman padat penduduk, dan analisis potensi kecelakaan di emplasemen stasiun diperoleh jenis kecelakaan yang sering terjadi, penyebab kecelakaan, dan bagaimana kronologi kecelakaanya.

Dari hasil analisis pada penelitian ini dapat memberikan masukan kepada PT. Kereta Commuter line Jakarta untuk melakukan perbaikan terhadap daerah - daerah yang rawan terjadi kecelakaan seperti sterilisasi kegiatan di sekitar jalur keretaapi dan pembuatan akses tidak sebidang (underpass atau jalur elevated). 


\section{PENDAHULUAN}

Jalur KA lintas Jatinegara - Jakartakota sepanjang 11,5 km sepur untuk akses melalui stasiun manggarai terdapat 9 stasiun dengan kondisi jalur kereta api yang berada diatas jalan raya (over pass rail way) yang dimulai dari stasiun cikini sampai dengan stasiun jayakarta, dan stasiun gambir yang merupakan juga stasiun untuk kereta api jarak jauh sedang akses dari stasiun senenmenuju ke stasiun jakarta kota melintasi 5 stasiun dengan 8 perlintasan sebidang.

Pada jalur KA lintas Jatinegara - Jakartakota dari latar belakang pendahuluan dapat dilihat dari permasalahannya seperti: adanya anjlogan, adanya orang yang tertabrak kereta api di jalur dan jembatan, adanya kecelakaan antara kendaraan dan kereta api, adanya orang terjatuh dari peron, dan adanya orang yang menerobos dan menyeberang jalur KA dan jembatan yang berasal dari pemukiman padat disekitar jalur ka dan jalan raya

Dengan dilakukannya penelitian ini sangat penting untuk karena dapat membantu institusi pemerintah dan BUMN terkait seperti Direktorat Jenderal Perkeretaapian, Pemerintah DKI Jakarta, dan PT. Kereta Api Indonesia (Persero) dalam rangka pemberian informasi melalui sebuah produk peta daerah rawan kecelakaan yang disusun berdasarkan dan sebenarnya sehingga masyarakat umum pengguna jasa dapat mengetahui dan dapat menghindari dana tau mentaati apa yang telah diinstruksikan dalam peta tersebut sehingga penyelenggaraan perkeretaapian dapat lancer dan kecelakaan dapat dihindarkan.

\section{METODE PENELITIAN}

Penelitian dilakukan diwilayah operasi daops 1 Jakarta yakni pada jalur Kereta api lintas Jatinegara - Jakartakota akses stasiun senen. Terkait dengan geometric jalan rel, komponen jalan rel Hidrolika pada jembatan, kondisi struktur perlintasan dan daerah pemukiman padat disekitar jalur keretaa api.

Sedangkan langkah-langkah yang dilakukan dalam penelitian ini adalah:

a. Survey pemeriksaan jalur dan jembatan KA, emplasemen dan perlintasan sebidang dan pemukiman padat penduduk disekitar jalur KA.

b. Variabel jumlah pelanggaran melalui analisa chi kuadrat satu sampel. Sedang pembahasan yang dilakukan adalah membahas daerah peotensi kecelakaan pada jalur jembatan KA, emplasemen dan perlintasan sebidang serta pemukiman padat penduduk disekitar jalur ka 


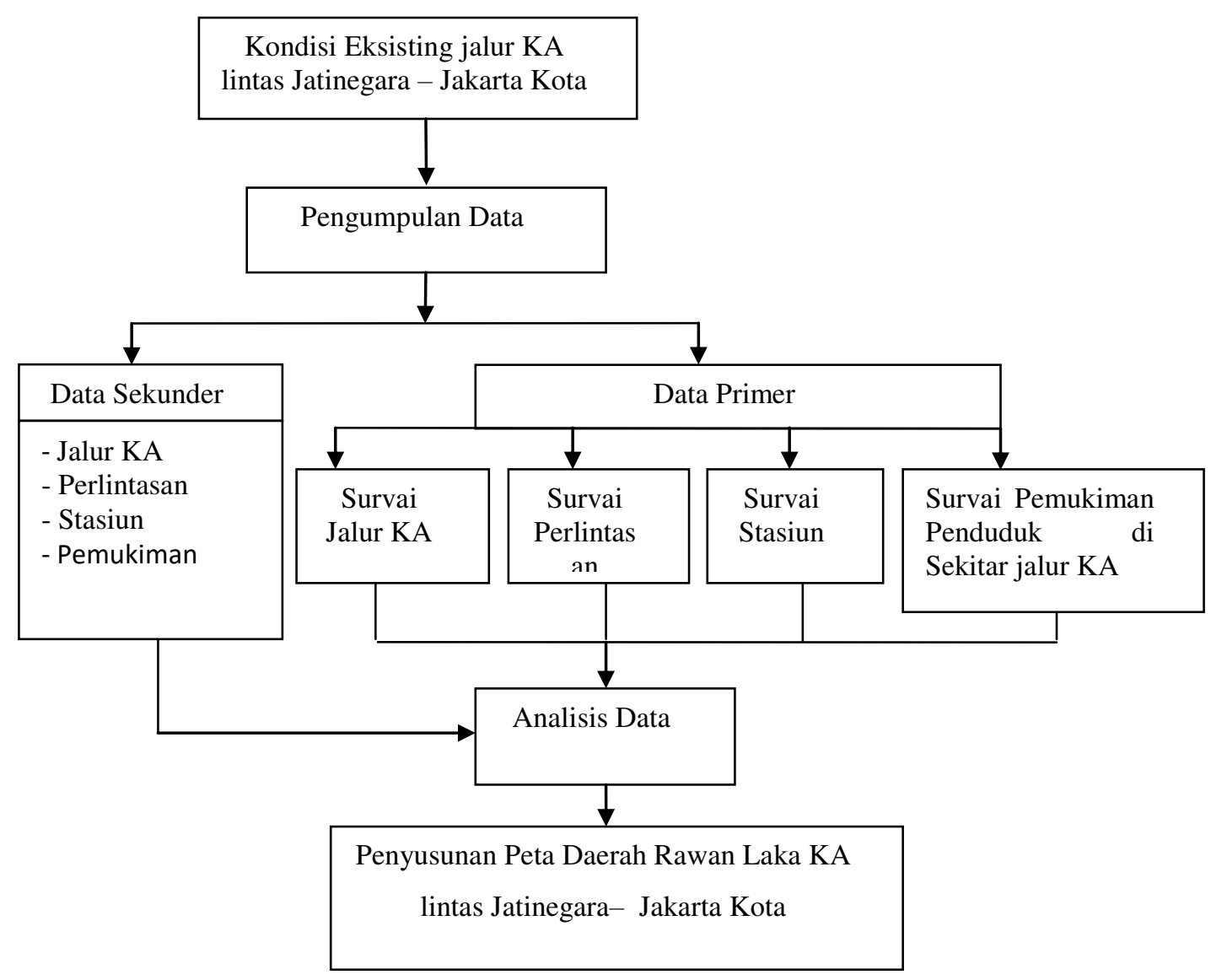

Metode Penelitian terdiri dari desain jalur KA dan jembatan , perlintasan sebidang dan daerah pemukiman disekitar jalurKA, data GAPEKA dan data kecelakaan dari kepolisian serta data jaringan jalan untuk akses perlintasan dari Kementerian PU dan data kepustakaan dari PT KAI serta STTD, sedangkan pengamatan secara langsung dilapangan melalui survey inventarisasi jalur dan jembatan KA, survey emplasemen stasiun jatinegara, senen dan Jakarta kota, survey perlintasan sebidang pada lintas jatinegara - Jakarta kota dan survey pemeriksaan geometric jalur dan jembatan KA, komponen jalan rel,tubuh jalan KA, draina seserta survey pengamatan perilaku orang di pemukiman padat di sekitar jalur keretaapi.

Guna mendapatkan hasil yang optimal maka dilakukan analisa pengolahan data melalui analisa deskriptip dengan melihat variabel teramati sebagai berikut :

a. Analisa dan pembahasan potensi kecelakaan di jalur dan jembatan ka Membahas kondisi geometrik, tubuh jalan rel, drainase dan komponen jalan rel yang dikaitkan dengan jadwal pemeriksaan rutin dan pemeliharaan secara keseluruhan.

b. Analisa dan pembahasan potensi kecelakaan di perlintasan sebidang membahas kondisi geometrik, struktur,drainase, komponen jalur KA dan kondisi serta kapasitas 
jalan dan perilaku manusia di lokasi daerah perlintasan sebidang yang dijadikan obyek penelitian

c. Analisa dan pembahasan potensi kecelakaan disekitar jalur KA yang berdekatan dengan pemukiman padat membahas kondisilahan, dan berbagai program yang telah dilakukan oleh pemerintahdaerah DKI JAKARTA dan PT KA seperti pembuatan pagar pengaman ,perbaikan dan pembuatan pagar pengamans ertasosialisasi keselamatan perjalanan kereta api.

d. Analisa dan pembahasan potensi kecelakaan di jalur emplasemen stasiun membahas akses perpindahan kereta oleh penumpang yang melintas sepur yang sebidang dengan jalan orang/penumpang serta kepadatan kereta api di emplasemen

\section{HASIL PEMBAHASAN}

Dari hasil survey yang telah dilakukan dilapangan yakni survey pemeriksaan jalur dan jembatan ka lintas jatinegara - jakarta kota dapat dijelaskan sebagai berikut :

\section{Lintas Jatinegara - Stasiun Pasar Senen}

a. Pemeriksaan Geometrik

Pemeriksaan geometrik untuk lintas jatinegara - senen km $11+750-\mathrm{km} 6+145$ yang terdiri dari pemeriksaan ruang bebas, lebar sepur,kelurusan rel, kerataan rel dan kelandaian rel dengan hasil masih sesuai dengan standar yang dikeluarkan oleh ketentuan yang belaku yakni ruang bebas untuk 2 sepur dengan sinyal elektrik dan dapat dipergunakan untuk angkutan ka penumpang dan ka barang kontainer terbesar ( 60 feet ) dengan jarak sumbu untuk jalur lurus dan lengkung sebesar $4 \mathrm{~m}$ dan mempunyai jari jari > $3000 \mathrm{~m}$ serta lebar sepur $1067 \mathrm{~mm}$, kelurusan rel ,kerataan rel dan kelandaian sebesar 1 permil dalam kondisi baik.

b. Pemeriksaan komponen jalan rel Pemeriksaan komponen jalan rel dilakukan secara langsung dengan hasil sebagai berikut : jenis rel adalah R 54 dari km 11+ $750-\mathrm{km} 6+145$ denganbantalanbeton ,penambat pendrol untuk jalur lurus, sedangjalur pengarah tersedia weselmasing masing sepur adalah wesel kiri dari arah sta.senen dan wesel kanan dari arah sta. Jatinegaraserta ada beberapa sepur dilayani oleh wesel inggris dengan tg $\alpha$ rata rata ukuran $1: 12$ dengan menggunakan bantalan kayu penambat baut dan didukung oleh balas yang teksturnya masih dalam kondisi baik. 
c. Pemeriksaan badan jalan

dindingpenahantanah dari pasangan batu kali yang dibangun untuk memproteksi struktur dari badanjalanrel pada lintas jatinegara - senen teramati masih dalam kondisi kokoh dan baik

d. Pemeriksaankonstruksijembatan

Bangunan Hikmat ( BH ) yang terdapat pada jalur kereta api lintas sta.jatinegara sta senen tidak terdapat jembatan dengan bentang yang panjang namun terdapat beberapa box culvert dengan bentang bervariasi yakni antara 3 sampai dengan $5 \mathrm{~m}$ yang terlihat masih dalam kondisi aman.

\section{Lintas Stasiun Pasarsenen - Stasiun.Jakartakota}

a. Pemeriksaan geometrik

pemeriksaan geometrik untuk lintas jatinegara - senen $\mathrm{km} 6+145-\mathrm{km} 0+135$ yang terdiri dari pemeriksaan ruang bebas,lebar sepur,kelurusan rel, kerataan rel dan kelandaian rel dengan hasil masih sesuai dengan standar yang dikeluarkan oleh ketentuan yang belaku yakni ruang bebas untuk 2 sepur dengan sinyal elektrik dan dapat dipergunakan untuk angkutan ka penumpang dan ka barang kontainer terbesar ( 60 feet ) dengan jarak sumbu untuk jalur lurus dan lengkung sebesar $4 \mathrm{~m}$ dan mempunyai jari jari > $3000 \mathrm{~m}$ serta lebar,kelurusan, kerataan rel dan kelandaian yang dalam kondisi baik.

b. Pemeriksaan komponen jalan rel

Pemeriksaan komponen jalan rel dilakukan secara langsung dengan hasil sebagai berikut : jenis rel adalah R 54 dari $\mathrm{km} 10+473-\mathrm{km} 6+145$ denganbantalanbeton ,penambat pendrol untuk jalur lurus ,sedangjalur pengarah /wesel menggunakan wesel inggris, wesel kiri dan kanan dengan bantalan kayu dengan penambat baut dan didukung oleh balas yang teksturnya masih dalam kondisi baik.

c. Pemeriksaan badan jalan

Dinding penahan tanah dan proteksi untuk kostruksi badan jalan rel pada lintas jatinegara - senen juga masih dalam kondisi baik.

d. Pemeriksaan konstruksi jembatan

Bangunan Hikmat ( BH ) antar sta. kampong bandan dan sta rajawali lintas Jakarta kota - pasar senen pada sepur hulu maupun hilir terdiri dari jembatan rangka baja tipe pratt dengan bentang $40 \mathrm{~m}$ terdiri 2 bentang merupakan jembatan rangka baja yang masih dalam kondisi sangat baik dikarenakan pada tahun 2012 telah dilakukan proses perbaikan baik untuk struktur bagian atas dan struktur bagian 
bawah.seperti kita ketahui jembatan tersebut sangat dekat dengan jalan utama yaitu jalan gunung sahari dengan aktifitas pergerakan ekonomi yang sangat tinggi dan terdapat pemukiman padat penduduk sehingga penduduk sekitar sering menggunakan jembatan tersebut untuk memperpendek akses oleh karena itu sangat membahayakan pergerakan kereta api yang sedang melintas .

Sedang konstruksi bangunan bawah (pondasi) terdiri dari 2 buah abutment dengan perletakan tumpuan sendi dan rol dan ditengah bentang ditopang oleh pilar dengan pondasi tiang pancang. Kondisi muka air banjir masih terpantau dalam kondisi aman yakni masih berada $92 \mathrm{~cm}$ dibawah gelagar induk jembatan tersebut.Bersama ini disampaikan pula gambar jalur ka lintas senen - Jakarta kota.gambar 1 jalur ka lintas sta.jatinegara- jakarta kota melalui pasar senen.

Jumlah perlintasan sebidang pada jalur jatinegara - jakarta kota terdapat 28 perlintasan KA yang sebidang dengan jalan dan Pemeriksaan hanya dilakukan pada perlintasan sebidang yang berpotensi terjadinya kecelakaan dengan didasarkan pada status perlintasan ,panjang antrean,kondisi perlintasan kapasitas jalan serta fasilitas peralatan perlengkapan jalan dan perilaku pengguna jalan serta jumlah kejadian kecelakaan yang terjadi 5 tahun terakhir adalah di perlintasan sebidang jpl no 46, perlintasan sebidang jpl no 36, dan perlintasan sebidang jpl no 23.

Contoh: Perlintasan sebidang jpl 46 Pondok Jati

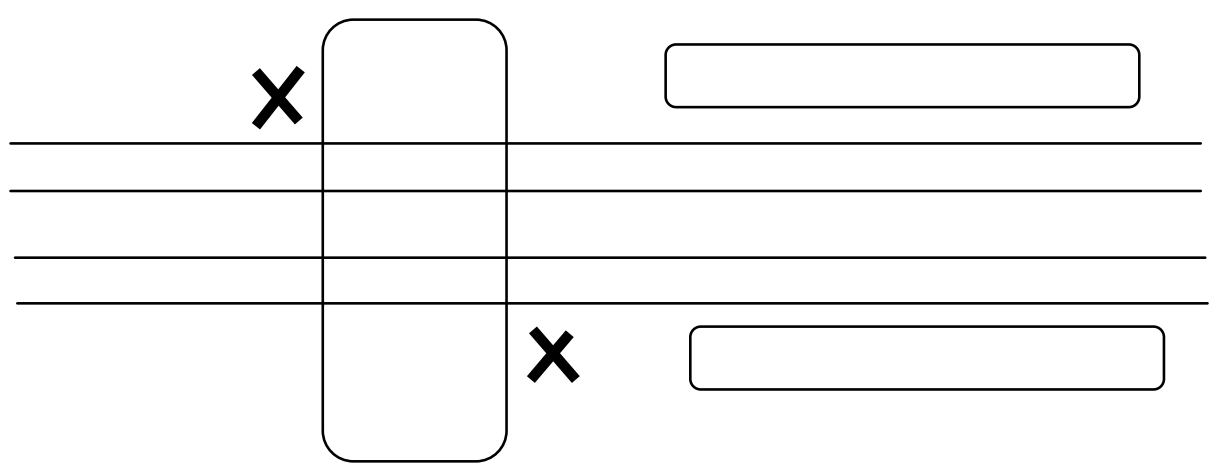

Sedangkan Potensi Kecelakaan di Sekitar Pemukiman Padat penduduk yaitu, Antar Stasiun Jatinegara - Stasiun Pondokjati, Antara Stasiun Pondokjati - Stasiun Kramat, Antara Stasiun Kramat - Stasiun.Gangsentiong, Antara Stasiun gangsentiong - Stasiun senen, Antara Stasiun Pasarsenen- Stasiun Kemayoran, Antara Stasiun Kemayoran Stasiun Rajawali, Antara Stasiun Rajawali- Stasiun, Kampung Bandan, Antara Stasiun Kampung Bandan - Jakarta kota, tetapi terdapat berpotensi kecelakaan di emplasemen 
stasiun adalah sebagai berikut Stasiun Jatinegara, Stasiun Pasarsenen, Stasiun Kemayoran, Stasiun Rajawali, Stasiun Kampungbandan, Stasiun Jakarta Kota.

Contoh: Perlintasan Jalur Pemukiman penduduk di jalur Ka Lintas Jatinegara-Pondok Jati
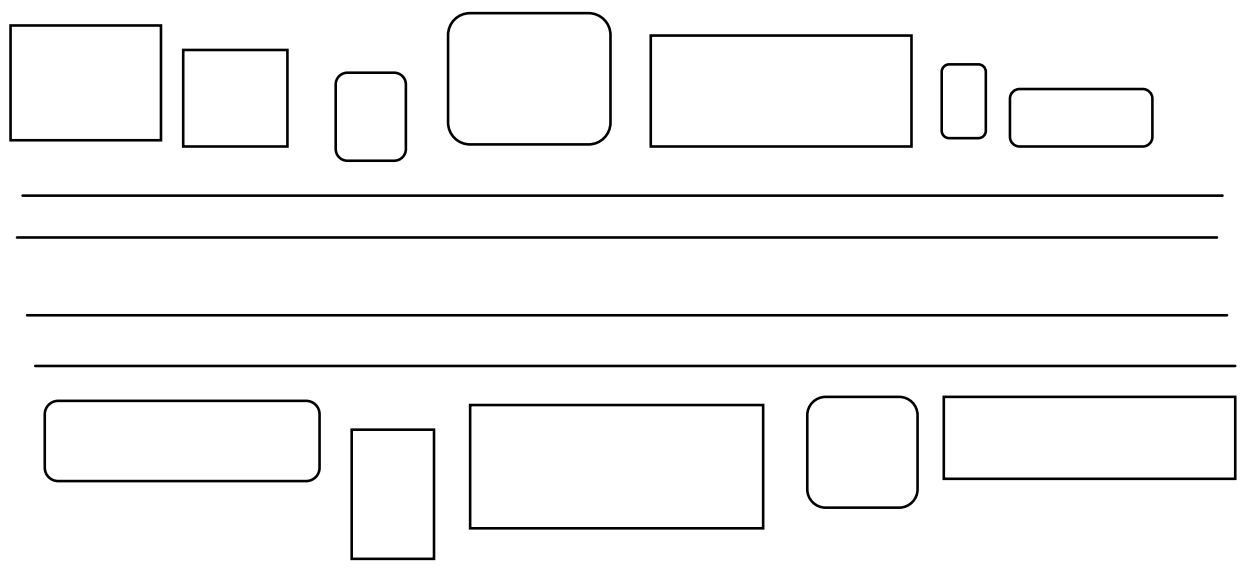

Contoh: Emplasemen stasiun Jatinegara

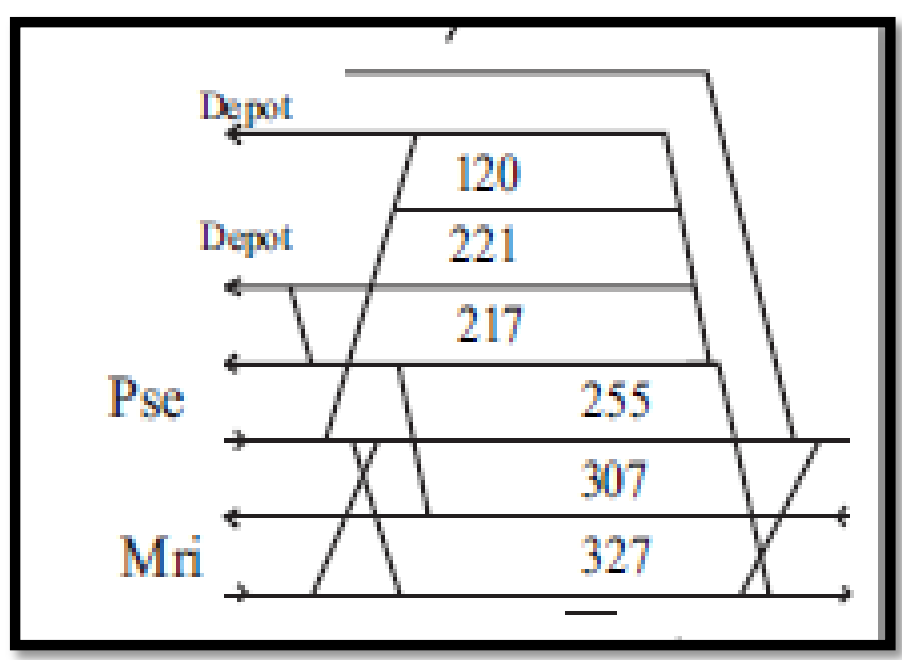

\section{KESIMPULAN DAN SARAN}

\section{Kesimpulan}

1. Kondisi jalur dan jembatan perlu dilakukan sterilisasi terhadap segala kegiatan baik untuk melintas dan menyusuri serta untuk kegiatan jual dan beli seperti yang terdapat diantara jalur ka lintas stasiun gang sentiong menuju staiun senen karena pada jalur ini terdapat pergerakan kereta api yang sangat tinggi yakni 14 pergerakan kereta apimjarak jauh dan 96 pergerakan kereta apiu commuter line.

2. Kondisi jalur emplasemen yang masih sebidang dengan jalur kereta api yang sangat mengganggu kenyamanan penumpang pada saat penumpang pindah jalur untuk 
pindah kereta api dan juga sangat membahayakan penumpang pada saat melintas jalur kereta api.

3. Kondisi perlintasan sebidang yang semakin padat dan menimbulkan antrean yang cukup panjang seperti pada perlintasan gang sentiong dengan antrean panjang 19 m,pondok jati $22 \mathrm{~m}$ dan perlintasan bungur kemayoran dengan panjang antrean $40 \mathrm{~m}$

4. Kondisi stasiun jakarta kota dan kampung bandan yang masih tergenang air apabila curah hujan tinggi akibat drainasee yang buruk

\section{Saran}

1. Pembuatan dan perbaikan pagar yang terbuat dari dinding beton yang dibangun di sepanjang jalur ka lintas jatinegara - stasiun senen.

2. Pembuatan akses yang tidak disebidang baik distasiun awal dan akhir serta di stasiun antara yang melayani angkutan komuter line jabodetabek lintas jatinegara - jakarta kota.

3. Melaksanakan sosialisasi secara periodik dan terus menerus kepada masyarakat disekitar jalur ka jembatan tentang keselamatan perjalanan kereta api dan bahaya yang mengancam jiwa manusia.

4. Untuk perlintasan gang sentiong dan pondok jati bila sulit untuk dilakukan pembuatan under pass maka dapat ditutup dengan membuat akses baru dan untuk perlintasan bungur dapat dibuat under pass.

\section{DAFTAR PUSTAKA}

1. , 2011. Peraturan Menteri Perhubugnan Nomor PM.32 Tahun 2011Tentang Standard an Tata Cara Perawatan Prasarana Kereta Api , Jakarta.

2. Direktorat Keselamatan Perkeretaapian, . Investigasi Kecelakaan Kereta Api, Jakarta.

3. Setyowarno, $\mathrm{Joko}_{2}$. Jalan Rel. 